It is pointed out that the force of the detonating explosive momentarily creates a thin zone of melted metal between the carbon steel base-plate and the stainless steel 'skin' in this case, resulting in the effective welding of the two metals together. A photomicrograph included in the article convincingly shows the bond between the two steels as joined by the explosives.

The process has been extended by the Explosives Department to the production of developmental quantities of steel plate with claddings of nickel, nickel alloys, cupro-nickel, copper, brass, titanium and several special alloys. Steel plates can be clad with metal skins from $1 / 16$-in. to 1 -in. thick, depending on the nature of the cladding material, and surface areas up to $140 \mathrm{sq}$. ft. have been successfully realized.

A most rigorous laboratory-testing programme was concurrently designed to prove the high quality of these explosive-bonded materials. This included ultrasonic inspection, bend and bond-strength tests, hardness measurements, corrosion and thermal resistance investigations. "In thermal-resistance tests, the new materials have withstood repeated cycles of $1,000^{\circ} \mathrm{F}$., followed by quenching. They also have been heated to peak temperatures of $1,750^{\circ}$ to $2,000^{\circ} \mathrm{F}$. and then quenched without failure." It is further claimed that explosively bonded plates can be cut and trimmed ". . by shearing, sawing, flame cutting, abrasive-wheel or plasma-are eutting, planing, milling or grinding. In addition, they can be formed by both hot and cold shop methods, including rolling, pressing and flanging, without bond separation."

There would appear to be little doubt as to the commercial feasibility of this new explosives metal-bonding process in view of these results; incidentally, it opens up a now vista in the use of explosives as a versatile industrial tool, one which, subject to obvious safeguards, must inevitably command the interest of all concerned with metal cladding.

\title{
FOLK-LORE AND FOLK-LIFE IN BRITAIN
}

\begin{abstract}
$\mathrm{T}$ HE formution in 1961 of the Society for Folk Life Studies met a long-felt wart among scholars engaged on research into the traditional ways of life in Great Britain and Ireland. Publication of a journal was planned to be one of the Society's chief functions, and the first volume, containing eight articles ranging over a diversity of subjects, sets an initial high standard of research and authorship *.

Miss Anne Buck, keeper of the Gallery of English Costume in Manchester, contributes an excellent study of the countryman's smock which does much to dispel the many fanciful theories so often held about these interesting traditional garments.

The craft of bowl-turning and spoon-making is described by Mr. F. Geraint Jenkins of the Welsh Folk Museum, and that of hand wool-combing by Mr. H. Lemon of the Wool Industries Research Association. Both these articles are well illustrated by photographs which show in detail the various processes of the crafts described.

Mr. F. Atkinson, director of the Bowes Museum, Barnard Castle, writes fully on "Knur and Spell and Allied Games"
\end{abstract}

\section{NUTRITION IN BRITAIN 1950-60}

$\mathrm{B}^{\mathrm{n}}$ ETWEEN 1940 and 1949 the National Food Survey of the Ministry of Agriculture, Fisheries and Food published two reports on Domestic Food Consumption Expenditure in the United Kingdom, and since 1950 has issued reports annually. These are based on surveys of households of different family composition and income in different parts of the country; they not only show average domestic food consumption and expenditure, but also make comparisons for regions, family size and income. The nutritional value of the food consumed is calculated and compared with a standard of requirements (the British Medical Association standard) considered necessary for satisfactory health and physical development. The reports are the only easily accessible source of information on food consumption and its trends in the United Kingdom. No other country undertakes annual national surveys of this nature.

Mr. R. Lambert has made a critical study of the reports from 1950 to $1960 *$. While admitting that they are of great value in showing national trends in consumption,

- Nutrition in Britain 1950-60: a Critical Discussion of the Standards and Findings of the National Food Survey. (Occasional Papers on Social Administration, No. 6.) By Royston Lambert. Pp. 46. (Welwyn: The Codicote
Press, 1964.) 78. 6d. in an article which helps to clear up a great deal of confused thinking about the methods of play and the locale of such games.

It is a criticism often levelled at folk-life and folk-lore scholars that their interests are mainly rural. This is confounded in an excellent article by Mr. D. McKelvie, English lecturer at Swinton Teachers' Training College, on "Aspects of Oral Tradition and Belief in an Industrial Region". Mr. McKelvie has carried out a detailed investigation of working-class life in modern Bradford, and the result is a fascinating survey of the homes, the minutix of daily life, even of the folk-lore of an urban community to-day. Mr. McKelvie is to be congratulated on his piece of research which goes far deeper than the usual economic or sociological survey so often made. His work will, we hope, be followed in other areas-in new towns, for example, or in the vast housing estates growing up as adjuncts to our more ancient cities. * Folk Life, 1. (Journal of the Society for Folk Life Studies.) Pp.
112+24 plates. (Cardiff: Folk Life Society, e/o St. Fagan's Castle,
1963).

he considers that they do not direct sufficient attention to findings which suggest that the nutrition of large families is unsatisfactory. He implies that facts are being collected for facts' sake and do not lead to action on the part of the Government. He also criticizes methods of presentation and discusses the difficulties of using dietary standards to assess nutritional levels. He believes that the survey should have broader terms of reference, that is, it should be extended by investigations of the state of nutrition of vulnerable groups, involving anthropometric, clinical and biochemical studies. By extrapolating the survey data to Britain as a whole, he estimates that a third of the population is living in households obtaining less than requirements for two major nutrients-or only just obtaining requirements-while 25 and $12 \cdot 5$ per cent are in the same position for three and four nutrients respectively. This relates, of course, only to requirements in terms of the British Medical Association standard, and does not mean that clinically evident malnutrition exists in the sections of the population concerned. He considers that certain figures for height from large families provide some indication of unsatisfactory nutrition.

Mr. Lambert's implication that the survey minimizes disquieting facts is somewhat unfair. The findings are 